\title{
Effect of Gliricidia (Gliricidia sepium) Leaf Meal Blocks on Intake, Live Weight Gain and Milk Yield of Dairy Cows
}

\author{
S.C. Somasiri", S. Premaratne ${ }^{1}$, H.A.J. Gunathilake², H.A. Abeysoma² \\ C.M.B. Dematawewa ${ }^{1}$ and J.H.M.N. Satsara ${ }^{2}$ \\ Postgraduate Institute of Agriculture \\ University of Peradeniya \\ Sri Lanka
}

\begin{abstract}
The objective of the present study was to find the effect of feeding of Gliricidia (Gliricidia sepium) leaf meal blocks on intake, live weight gain and milk yield of dairy cows. Two types of Gliricidia leaf meal blocks (B1 and B2) were prepared and compared with a control diet of grass and straw. Gliricidia leaf meal blocks were prepared using Gliricidia leaf meal, coconut (Cocos nucifera) poonac and rice (Orvza sativa) bran. A feeding trial was conducted according to $3 \times 3$ Latin square design using lactating cows. Treatments were basal diet (T1), basal diet with B1 (T2) and basal diet with B2 (T3). Basal diet consisted of Brachiaria brizantha, Coimbatoor 3 (Pennisetum perpureum $x$ Pennisetum americarnum) and rice straw. Data were statistically analyzed using general linear model procedure in SAS version 8. Average dry matter intake of cows fed with both types of blocks were higher $(p<0.05)$ compared to control diet. Similarly, live weight gain of cows fed with Gliricidia leaf meal blocks were also higher compared to the group fed with the control diet. Milk production was not affected by treatments. However, average milk production of cows fed with T3 (basal feed + B2) was significantly $(p<0.05)$ higher $(2.4 \mathrm{~L} /$ day/cow) than the other two treatments. Therefore, Gliricidia leaf meal block (B2) prepared with coconut poonac and rice bran can be recommended as the best block having favourable nitrogen and energy balance among the three diets, to be used with a roughage diet for indigenous cross bred cows.
\end{abstract}

Key words: Dairy cows, Gliricidia leaf meal blocks, Supplementation

\section{INTRODUCTION}

Rearing livestock is an integral part of the farming systems under coconut in many areas of Sri Lanka. It provides a steady income throughout the year with less risk than intercropping. Particularly in the coconut triangle, ruminant animals are mainly reared under semi intensive management system with tethered grazing. The main feed resources available are grasses and weeds grown under coconut and other perennials. Ruminants also help control the weeds thereby, reduce the cost of weeding. According to Liyanage, (1999) coconut production has shown an increase by $20-25 \%$ after three years of practice of coconut livestock farming systems.

\footnotetext{
1* To whom correspondence should be addressed: sharinsc@yahoo.com Department of Animal Science, Faculty of Agriculture, University of Peradeniya, Peradeniya, Sri Lanka ${ }^{2}$ Coconut Research Institute, Lunuwila, Sri Lanka
} 
One of the major constraints faced by the dairy farmers in the coconut triangle is the severe drop in body condition during prolonged droughts (Ibrahim and Jayatileka, 2000) due to scarcity of feed. Therefore, forage diets need to be supplemented with an additional energy or protein source (concentrates) and minerals to satisfy the cows' nutritional requirements (Ranawana, 2008). In order to ensure a steady supply of quality feeds for livestock even during the dry season, excess forages could be preserved as silage, hay and leaf meal blocks (Premaratne, 1993; Somasiri et al., 2010). Gliricidia is widely used as a source of nitrogen for ruminants, especially during dry spell. It could be fed as a fresh diet or in dried form as leaf meals. According to Somasiri et al. (2010), Gliricidia leaf meal can be formed into blocks to improve the keeping quality using a briquette machine applying hydraulic pressure. Furthermore, these blocks can be improved nutritionally by mixing leaf meal with other feed ingredients such as coconut poonac and rice bran, and could be stored up to three months without deteriorating the quality, if packed properly. They can also be used as an effective feed for livestock, especially for dairy cows during the drought period. Therefore, the main objective of the present study was to find the effect of feeding of Gliricidia leaf meal blocks on intake, live weight gain and milk yield of dairy cows.

\section{MATERIALS AND METHODS}

A feeding trial was conducted at Coconut Research Institute (CRI), Lunuwila using indigenous cross bred dairy cows (Indigenous x Sahiwal) to find the effect of feeding of Gliricidia leaf meal blocks on their intake, live weight gain and milk yield. Two types of Gliricidia leaf meal blocks were prepared and compared with a control diet of grass and straw. Gliricidia leaf meal blocks were prepared using the following recipes; $75 \%$ Gliricidia leaf meal $+25 \%$ coconut (Cocos nucifera) poonac $\left(\mathrm{B}_{1}\right)$ or $75 \%$ Gliricidia leaf meal $+12.5 \%$ coconut poonac $+12.5 \%$ Rice (Oriza sativa) bran $\left(\mathrm{B}_{2}\right)$.

Six milking cows having an average body weight of $311 \mathrm{~kg} \pm 17.8$ in the latter stages of lactation ( $1.8 \mathrm{~L} \pm 0.26$ per day, around 210 days of lactation) were arranged in a Latin Square design (3x3) (Gomez and Gomez, 1976) for the experiment (Table 1).

Table 1. Latin square design of the treatments

\begin{tabular}{lccc}
\hline Treatment & \multicolumn{3}{c}{ Experimental period } \\
\cline { 2 - 4 } & \multicolumn{3}{c}{$\mathbf{2}$} \\
\cline { 2 - 4 } & 4 and 5 & Cow number \\
\hline Treatment $1\left(\mathrm{~T}_{1}\right)$ & 2 and 3 & 1 and 6 \\
Treatment $2\left(\mathrm{~T}_{2}\right)$ & 1 and 6 & 1 and 6 & 4 and 5 \\
Treatment $3\left(\mathrm{~T}_{3}\right)$ & 4 and 5 & 2 and 3 \\
\hline
\end{tabular}

The cows were divided into two groups according to their body weight, age and number of calving. Animals in a particular group were randomly assigned to the three treatments such that each treatment had 2 animals representing two groups in a given experimental period (Table 1). Brachiaria brizantha, Coimbatore 3 (CO3-Pennisetum perpureum x Pennisetum americarnum) fodder and rice straw were given as basal feed for cows based on their availability as a common feed. Both straw and fodder were obtained from nearby fields in Rathmalagara, Madampe (Low Country Intermediate Zone). 
The cows were introduced to the experimental site (cow shed) and kept for an adaptation period of 2 weeks. During the adaptation period, cows were treated for ticks and fed with the basal diet of grass and rice straw along with two table spoons of mineral mixture (Calcium, phosphorous, magnesium, potassium, sodium, copper, zinc, cobalt and selenium Premix) per cow. Feed was offered ( $10 \%$ of body weight on fresh weight basis) twice per day (6.00 a.m. 8.00 a.m. and 16.00 p.m. - 18.00 p.m.). Milking was carried out once per day at 4.00 a.m.

Two types of blocks $\left(\mathrm{B}_{1}\right.$ and $\left.\mathrm{B}_{2}\right)$ were introduced gradually during the preliminary period (2 weeks). The number of blocks was increased gradually up to a maximum of two leaf meal blocks per day per cow. Leaf meal blocks were broken into pieces and water was added to make a pulp before feeding. Mineral mixture was added to the pulp for treatment groups. Treatments were Basal diet $\left(T_{1}\right)$, Basal diet with $B_{1}\left(T_{2}\right)$ and Basal diet with $B_{2}\left(T_{3}\right)$. Number of blocks given to an animal in the feeding trial was limited to two blocks from $\mathrm{B}_{1}$ or $\mathrm{B}_{2}$.

Weekly body weights, daily milk yields and daily feed intake of cows were measured after the preliminary period. Body weight was measured using the weight band (Farmer's Boy Patent No. 812717). Collection period was 2 weeks. Once the data collection of the first experimental period was completed, cows were given two weeks rest period to overcome the "carryover effect" from the previous treatment. During this period, cows were tethered under coconut three times a day during the day time and paddocked in the shed during the night. At the start of the second experimental period, two animals in the group were assigned a different diet. Allocation of treatment was such that animals in a particular treatment were not allotted to the same treatment again in the second experimental period (Table 1). Before commencing the next experimental period, preliminary period of one week was allowed for cows to get used to new treatment diet. Then collection period was continued for two weeks. The same procedure was continued in the third experimental period. Accordingly, three experimental periods were conducted with 6 replicates per treatment using the same sets of cows.

Water was given twice a day (6.00 a.m. - 8.00 a.m. and 16.00 p.m. - 18.00 p.m.). Free access to water was not allowed due to practical problems such as leaking of water to feed troughs. Weight of the feed offered and refused were recorded daily at each feeding during the collection period. Samples of feed, test diets and refusals were collected, composted, dried $\left(60^{\circ} \mathrm{C}\right)$ and stored in paper bags for further analysis. During the analysis, all the samples were ground to pass through a $1 \mathrm{~mm}$ mesh using a laboratory mill and analyzed for dry matter (DM), total ash, crude fibre, crude protein and ether extract (AOAC, 1995). Data were statistically analyzed using cows as blocks along with the time in Latin Square Design. Body weight and milk yield of cows were adjusted for the initial values and adjusted means were compared with probability differences for significance with General Linear Model Procedure in SAS version 8 (Statistical Analysis Systems Institute Inc., 1999).

\section{RESULTS AND DISCUSSION}

Table 2 presents the nutrient composition of straw, grass, B1 and B2 used in the feeding trial. 
Table 2. Nutrient composition of feeds (\%) used in the feeding trial

\begin{tabular}{lccccc}
\hline Feed & DM & CF & EE & CP & Ash \\
\hline Straw & 94 & 42 & 4 & 4 & 6 \\
Grass (dried) & 94 & 43 & 6 & 8 & 6 \\
B $_{1}$ & 92 & 22 & 9 & 21 & 7 \\
B $_{2}$ & 92 & 24 & 9 & 20 & 8 \\
Coconut Poonac & 92 & 10 & 9 & 21 & 6 \\
Rice bran & 90 & 24 & 12 & 6 & 14 \\
\hline
\end{tabular}

B1 (Gliricidia leaf meal 75\%+ Coconut poonac 25\%)

B2 (Gliricidia leaf meal 75\% + Coconut poonac 12.5\% + Rice bran $12.5 \%$ )

Highest crude protein content was observed in leaf meal blocks, whereas crude fibre content, in all the ingredients was above $20 \%$ except for coconut poonac. Nutritional composition of straw and grasses are in agreement with other workers (Ibrahim et al., 1987). Highest ash content found in rice bran is in agreement with the work of Nguyen and Nguyen (2003).

\section{Feed intake}

Table 3 presents the mean dry matter feed intake of cows during three experimental periods. Dry matter feed intake of basal diet was higher in $T_{2}$ (basal diet + block 1 ) and $T_{3}$ (basal diet + block 2) compared to $\mathrm{T}_{1}$ (basal diet only). Numerous workers have reported that inclusion of low levels of legume foliage or grass increased the intake of fibrous basal diet (Ash, 1990; Kimambo et. al., 1992 and Premaratne, 1993) due to increased availability of fermentable nitrogen and other nutrients required by the rumen bacteria (Nguyen and Nguyen, 2003). When the intake of treatment blocks $\left(\mathrm{B}_{1}\right.$ and $\left.\mathrm{B}_{2}\right)$ was compared, intake of $\mathrm{T}_{3}$ was superior to $T_{2}$ indicating that $B_{2}$ was more palatable compared to $B_{1}$. This may be due to proper protein and energy balance. Total feed intake was significantly higher $(\mathrm{P}<0.05)$ in treatments $\mathrm{T}_{2}$ and $\mathrm{T}_{3}$ than $\mathrm{T}_{1}$ indicating that both leguminous blocks were palatable to animals, and supplementation of these blocks had enhanced the consumption of basal diets in treatments $\mathrm{T}_{2}$ and $\mathrm{T}_{3}$. It was observed during the feed trial that cows consumed the leguminous leaf meal block very quickly and it took only one hour for the cows to clear the supplement feed from troughs.

Grass and straw are generally considered as roughage that contain high fibre and is bulky in nature. As a result, feed intake is reduced and retention time of roughage in the rumen is increased. Therefore, intake of $T_{1}$ was low compared to supplemented diets, $T_{2}$ and $T_{3}$. However, supplementation of basal diet with Gliricidia leaf meal blocks may have increased the availability of nutrients to rumen microbes by rectifying energy and nitrogen imbalances in the rumen and stimulating the rumen microbial activity (Ibrahim, 2000). Reynolds and Cobbina, (1992) also stated that when roughage was supplemented with concentrates, it enhanced the feed digestibility and intake of animals. Nevertheless, Devendra, (1993), Stewart and Simons, (1994) and Nguyen and Nguyen, (2003) confirmed that when used as a supplement, the optimum level of fresh fodder trees and shrubs should be about $30-50 \%$ of the ration on dry matter basis. 
However, the amount of leguminous leaf meal blocks used in the present study was about $22 \%$ of the diet (dry matter basis) and it must have stimulated the microbial multiplication and activity in the rumen and thereby increased the feed intake of animals.

Table 3. Mean dry matter feed intake $\mathrm{kg} / \mathrm{d}^{1}$ of cows during the feeding trial

\begin{tabular}{lccc}
\hline Treatment & Basal diet intake & Treatment block & Total feed intake \\
\hline $\mathrm{T}_{1}$ & $5.8^{\mathrm{a}} \pm 2.7$ & - & $5.8^{\mathrm{b}} \pm 2.7$ \\
$\mathrm{~T}_{2}$ & $7.1^{\mathrm{a}} \pm 3.4$ & $1.8^{\mathrm{a}} \pm 0.3$ & $8.6^{\mathrm{a}} \pm 3.6$ \\
$\mathrm{~T}_{3}$ & $6.9^{\mathrm{a}} \pm 3.3$ & $2.0^{\mathrm{a}} \pm 0.0$ & $8.7^{\mathrm{a}} \pm 3.3$ \\
$\mathrm{SE} \pm$ & 0.42 & 0.08 & 0.42 \\
\hline
\end{tabular}

1 Average of 6 cows

Figures followed by different superscripts in a column differ significantly $(\mathrm{p}<0.05)$

$\mathrm{T}_{1}$ - Basal diet only

$\mathrm{T}_{2}$ - Basal diet + block 1 (Gliricidia leaf meal 75\%+ Coconut poonac 25\%)

$\mathrm{T}_{3}$ - Basal diet + block 2 (Gliricidia leaf meal $75 \%$ + Coconut poonac $12.5 \%$ + Rice bran $12.5 \%$ )

\section{Body weight and milk yield of dairy cows}

\section{Body weight}

There were 6 replicates per treatment as data were collected during 3 experimental periods according to the Latin Square Design. Live weights of animals were taken at the beginning of the experiment; end of first week and at the end of experimental period. The mean live weight gains of cows during feeding trial were calculated accordingly (Table 4).

As shown in Table 4, $T_{2}$ (basal diet + block 1 ) and $T_{3}$ (basal diet + block 2 ) had a mean live weight gain of 1.0 and $1.17 \mathrm{~kg}$ towards the end of experimental periods while, $\mathrm{T}_{1}$ (basal diet) has maintained only $0.67 \mathrm{~kg}$ mean live weight gain though the values did not differ significantly. The differences were not significant owing to the high variation observed among replicates within a treatment. However, the increase in body weights may be due to the extra nutrients (protein, carbohydrates, fats and minerals) received with the leaf meal blocks supplementation.

Table 4. The mean live weight gain and milk yield of cows during feeding trials ${ }^{1}$

\begin{tabular}{lcc}
\hline Treatment & $\begin{array}{c}\text { Mean live weight gain, } \\
\mathbf{k g} / \mathbf{1 4} \text { days }\end{array}$ & Mean milk yield (l/d) \\
\hline $\mathrm{T}_{1}$ & $0.67^{\mathrm{a}} \pm 1.3$ & $2.33^{\mathrm{a}} \pm 0.5$ \\
$\mathrm{~T}_{2}$ & $1.00^{\mathrm{a}} \pm 1.2$ & $2.22^{\mathrm{a}} \pm 0.7$ \\
$\mathrm{~T}_{3}$ & $1.17^{\mathrm{a}} \pm 1.1$ & $2.40^{\mathrm{a}} \pm 0.5$ \\
$\mathrm{SE} \pm$ & 0.14 & 0.09 \\
\hline
\end{tabular}

${ }^{1}$ Average of 6 cows

Figures followed by the same superscripts in a column do not differ significantly $(\mathrm{p}>0.05)$

$\mathrm{T}_{1}$ - Basal diet only

$\mathrm{T}_{2}$ - Basal diet + block 1 (Gliricidia leaf meal $75 \%+$ Coconut poonac $25 \%$ )

$\mathrm{T}_{3}$ - Basal diet + block 2 (Gliricidia leaf meal $75 \%+$ Coconut poonac $12.5 \%$ + Rice bran $12.5 \%$ )

Simbaya, (2002) also noted that fodder trees and shrubs have the capacity to promote all aspects of animal production when used as a supplement. According to Premaratne, (1993) and Seijas et al. (1994) high live weight gains were observed when the legume was offered daily.

Milk yield 
Milk yield was measured in each cow on a daily basis consecutively for 14 days during the collection period. Mean milk yield of cows is presented in Table 4. According to Table 4, diet did not have any significant $(p>0.05)$ effect on mean milk yield of cows. However, highest milk yield of $2.4 \mathrm{~L}$ was obtained from the cows fed with T3 (basal diet + Block 2) treatment which consisted of Gliricidia leaf meal with coconut poonac and rice bran compared to other treatments implying that the leguminous leaf meal supplementation to dairy cows increased the nutrient availability enhancing production of milk. The cows were in the latter part of lactation therefore, improvement of milk yield at this stage was not that visible.

Similarly, Jayasuriya, (1984) noted that supplementation of Gliricidia with either untreated or treated rice straw increased milk production in Surti buffaloes. According to the results of the present study, mean milk yield of cows receiving $T_{2}$ was lower compared to $T_{1}$ and $T_{3}$ by $5 \%$ and $8 \%$, respectively, even though the values were not significantly different. When the leaf meal block 2 was prepared, rice bran was included with Gliricidia leaf meal, so that it must have helped providing balanced nitrogen and energy to animals and thereby increased the milk yield of cows.

According to the present results, the supplementation of roughage diets with leguminous blocks $(22 \%$ on dry matter basis) increased the feed intake of cows. Supplementation also increased the mean body weight as well as the milk production of cows. This study was carried out during drought period. Hence, the quality and availability of forage was low during the experimental period. In addition, night feeding and concentrate feeding was not practiced in order to follow similar management condition carried out by average farmers in the area. Supplementation of blocks was limited to 2 blocks due to practical difficulties. In addition, the present study was carried out with crossbred cows who were at the latter part of their lactation. Hence, the influence on the milk yield could be marginal. Therefore, it is suggested to carry out the same study for a period of 1 to 2 months using milking cows at early lactation during drought season.

\section{CONCLUSION}

Supplementation of roughage diets with leaf meal blocks is effective especially during the drought season to enhance performance of dairy cows. Accordingly, Gliricidia leaf meal block 2 which consisted of Gliricidia leaf meal with coconut poonac and rice bran was more effective in enhancing milk production and weight gain compared to block 1 which had Gliricidia leaf meal and coconut poonac. Therefore, Gliricidia leaf meal block prepared with $75 \%$ Leaf meal $+12.5 \%$ coconut poonac $+12.5 \%$ rice bran (block 2 ) is the best leaf meal block out of the two leaf meal blocks tested in this study.

\section{ACKNOWLEDGEMENT}

Authors wish to express their sincere thanks to Director, Postgraduate Institute of Agriculture, University of Peradeniya, and Director and Staff of Coconut Research Institute (CRI), Estate staff of Rathmalagara Estate, CRI and Head and Staff of Department of Animal Science, Faculty of Agriculture, University of Peradeniya. Appreciation is also expressed to the National Science Foundation (NSF) for funding the Research Project. 


\section{REFERENCES}

AOAC (1995). Official Methods of Analysis, 16th Ed, Association of Analytical Chemists, Washington, DC.

Ash, A.J. (1990). The effect of supplementation with leaves from the leguminous trees Sesbania grandiflora, Albizia chinensis and Gliricidia sepium on the intake and digestibility of Guinea grass hay by goats. Ani. Feed Sci. Tech. 28. 255-232.

Devendra, C. (1993). Trees and shrubs as sustainable feed resources. In Proceeding VI World Conference on Animal Production. Edmonton, Alberta, Canada. 1, 119 -136.

Gomez, K.A. and Gomez, A.A. (1976). Statistical procedures for agricultural research. 2nd Ed. John Wiley \& Sons, New York, NY.

Ibrahim, M.N.M., Ketelaar, R.S., Tamminga, S., Zemmelink, G. and Meer, van der J. (1987). Nutritive value of commonly available ruminant feeds in Sri Lanka. Institute for Livestock Feeding and Nutrition Research, Lelystad, The Netherlands, Report. 181.34.

Ibrahim, M. N. and Jayatileka, T. N. (2000). Livestock Production under Coconut Plantations in Sri Lanka: Cattle and Buffalo Production Systems. Asian Australasian J. of Animal Sci. 13(1) 60-67.

Ibrahim, M.N.M. (2000). Dairy Cattle Production, University of Peradeniya. Peradeniya.

Jayasuriya, M.C.N. (1984). The potential for the better utilization of fibrous agricultural residues for animal feeding in Sri Lanka. Asia Livestock. 9 -12.

Kimambo, A.E., Makiri, A.M. and Shem, M.N. (1992). The use of Leucaena leucocephala supplementation to improve the utilization of maize stover by sheep. In J.E.S.Stares and A.N.Said (Eds). Complementary of feed resources for animal production in Africa. Proc. Joint Feed Resources Networks Workshop, Botswana. pp. 430.

Liyanage, M.de.S. (1999). A guide to scientific cultivation and management of coconut, Coconut Research Institute of Sri Lanka, Bandirippuwa Estate, Lunuwila (Sri Lanka).

Nguyen, van Hao and Nguyen, van Hiep (2003). Utilization of Gliricidia leaves (Gliricidia maculata) as a protein source for dairy goats. In Reg Preston and Brian Ogle (Eds). Proceeding of Final National Seminar Workshop on Sustainable Livestock Production on Local Feed Resources. HUAF-SAREC, Hue City.

Premaratne, S. (1993). Role of tree fodders in livestock feeding. In H.P.M.Gunasena (Ed) Multipurpose Tree Species in Sri Lanka. Research and Development. Proceedings, Fourth Regional Workshop on Multiple Trees in Sri Lanka. 77-79.

Ranawana, S. (2008). Dairy Industry in Sri Lanka: Problems and Prospects. Economic Review, Dairy Industry Problems and Prospects, Research Department, People's Bank, Head Office, Sir Chittampalam A. Gardiner Mawatha, Colombo 2, Sri Lanka. 
Reynolds, L and Cobbina, J. (1992). The Integration of Livestock Production in Alley Farming. The AFNETA Alley farming training manual - Source book for alley farming research. 2.Unit 4.

Seijas, J., Arredondo B., Torrealba, H. and Combellas, J. (1994). Influence of Gliricidia sepium, multi nutritional blocks and fish meal on live weight gain and rumen fermentation of growing cattle in grazing conditions. Livestock Research for Rural Development. 6.90 -100.

Simbaya, J. (2002). Potential of fodder tree/shrub legumes as a feed resource for dry season supplementation of smallholder ruminant animals. National Institute for Scientific and Industrial Research, Livestock and Pest Research Centre, Chilanga, Zambia. 69-76.

Somasiri, S.C., Premaratne, S., Gunathilake, H.A.J., Abeysoma, H.A. and Satsara, J.H.M.N. (2010). Development of a leguminous leaf meal block as an animal feed. Tropical Agricultural Research 21(4): 412-420.

Statistical Analysis Systems (SAS) Institute Inc. (1999). Statistical Analysis Systems Institute (SAS/STAT). User's Guide. Version 8, Carry, NC.

Stewart, J.L. and Simons, A.J. (1994). Gliricidia sepium, a multipurpose forage tree legume. In.Gutteridge, R.C and .Shelton, H.M (Eds.), Forage Tree Legumes in Tropical Agriculture (pp 30-48). Department of Agriculture, the University of Queensland, Queensland 4072, Australia. CAB International, Wallingford, Oxen OX10 8DE, UK. 